\title{
Investigation on the Contamination of Freshwater Fish with Herbicides (CNP, Chlomethoxynil, Benthiocarb and Molinate)
}

\author{
Sadao Watanabe, Shigenobu Watanabe and Kazutoshi Ito \\ Kanagawa Prefectural Public Health Laboratory, \\ Nakao-cho, Asahi-ku, Yokohama 241, Japan
}

(Received July 3, 1982)

\begin{abstract}
Investigations were made on whether or not freshwater fishes in the Sagami River were contaminated by the herbicides CNP (chloronitrofen), chlomethoxynil, molinate and benthiocarb (thiobencarb). Application of these herbicides to paddy fields is restricted during the rice planting season, so this investigation was carried out in July and the contamination levels of other months were compared. CNP was detected in all four species of fishes (pale chub, pike gudgeon, carp and crucian carp), and benthiocarb was detected in two species in July, 1980. The residual levels of CNP were from $0.055 \mathrm{ppm}$ to $0.61 \mathrm{ppm}$, and those of benthiocarb were $0.02 \mathrm{ppm}$ and $0.10 \mathrm{ppm}$. These values were similar to those found in pale chub, ayu, crucian carp and large mouth bass in July, 1981 tests; the residual levels of CNP were from $0.046 \mathrm{ppm}$ to $0.88 \mathrm{ppm}$ and those of benthiocarb from $0.04 \mathrm{ppm}$ to $0.11 \mathrm{ppm}$, respectively. But in September, 1981, the residual levels were below a detectable level or detected only in very low concentrations. The bioconcentration ratio (concentration level in fish/concentration level in water) of CNP was supposed to be 420-8,000 and that of benthiocarb 20-100, when estimated from the results of this investigation. But it was thought that the residual period in fish did not continued too long. Chlomethoxynil and molinate were not detected in any fish examined.
\end{abstract}

\section{INTRODUCTION}

It has been feared that herbicides applied to paddy fields flow out gradually with effluent water, causing contamination of rivers and organisms in the river. Nowadays in Japan, herbicides such as CNP (chloronitrofen, 2,4,6trichlorophenyl $4^{\prime}$-nitrophenyl ether), chlomethoxynil (2,4-dichlorophenyl 3'-methoxy-4'nitrophenyl ether), molinate (S-ethyl $N, N$ hexamethylenethiocarbamate) and benthiocarb (thiobencarb, S-4-chlorobenzyl $N, N$-diethylthiocarbamate) are used extensively and heavily in paddy fields ${ }^{1,2)}$ but their application is restricted during the rice planting season. There have been several reports on the contamination levels of certain kinds of herbicides in the aquatic environment, ${ }^{3-5)}$ and recently it was reported that CNP was detected in fish and shellfish. ${ }^{6-8)}$ In Kanagawa Prefecture there are only about 6,000 ha of paddy fields (about $1 / 400$ of the country's total paddy area), ${ }^{2)}$ and these are located mostly in the central and western parts of the prefecture.

For the surveillance of residual levels of herbicides (CNP, chlomethoxynil, molinate and benthiocarb) in fish, freshwater fish were caught in July of 1980 and 1981 in the Sagami River, which flows through central Kanagawa Prefecture. The residual levels of herbicides were measured and those levels were compared with September, 1981 levels to ascertain whether or not contamination was continuous. The level of contamination of these herbicides in river water and a comparison with the levels found in the fish were also studied. 


\section{MATERIALS AND METHODS}

\section{Chemicals and Reagents}

CNP (purity 99\%) and benthiocarb (purity above $98 \%$ ): Wako Pure Chemical Ind., Ltd. ; chlomethoxynil (purity 99\%): supplied by Ishihara Ind., Ltd.; molinate (purity above 99\%): supplied by Yashima Chemical Ind., Ltd. These chemicals were used as analytical standards.

Aceton, $n$-hexane, acetonitrile and anhydrous sodium sulfate: nano-grade for pesticide residue analysis, Wako Pure Chemical Ind., Ltd. Florisil: activated for 10 hours at $130^{\circ} \mathrm{C}$ (Floridin Co., U.S.A.)

\section{Instruments}

N-P FID Gas Chromatograph (N-P FID GC): Hewlett Packard 5880A (equipped with nitrogen-phosphorus detector), column; $2 \%$ OV-101 on Uniport HP 100/ 120 mesh, $0.5 \mathrm{~m} \times 2 \mathrm{~mm} \phi$ conditions; Col. Temp. $180^{\circ} \mathrm{C}$, Inj-Det. Temp. $230^{\circ} \mathrm{C}$, carrier gas $\mathrm{He} 50 \mathrm{ml} / \mathrm{min}$. FPD-Gas Chromatograph (FPD-GC): Shimadzu GC-5A (equipped with S filter), column; $5 \%$ OV-101 on Gaschrom Q 80/ 100 mesh, $1.5 \mathrm{~m} \times 3 \mathrm{~mm} \phi$ conditions; Col. Temp. $180^{\circ} \mathrm{C}$, Inj-Det. Temp. $210^{\circ} \mathrm{C}$, carrier gas $\mathrm{N}_{2} 60 \mathrm{ml} / \mathrm{min}$. ECD-Gas Chromatograph (ECD-GC): Shimadzu GC-3BE (equipped with ${ }^{63} \mathrm{Ni}$ detector), column; $5 \%$ OV-17 on Gaschrom Q 80/ 100 mesh, $1.7 \mathrm{~m} \times 3 \mathrm{~mm} \phi$

conditions; Col. Temp. $230^{\circ} \mathrm{C}$, Inj-Det. Temp. $260^{\circ} \mathrm{C}$, carrier gas $\mathrm{N}_{2} 90 \mathrm{ml} / \mathrm{min}$.

Gas Chromatograph-Mass Spectrometry (GCMS): Shimadzu LKB-9000

Homogenizer: Biotrone BT 20S (Biotrona, Switzerland)

\section{Materials}

The freshwater fishes were obtained with a casting net at a point about 10 kilometers up the stream from the mouth of river on July 9 and December 9, 1980, and July 13 and September 18, 1981. Figure 1 shows the sampling point.

\section{Analytical Method of Fish}

Dozens of each species of fish were collected

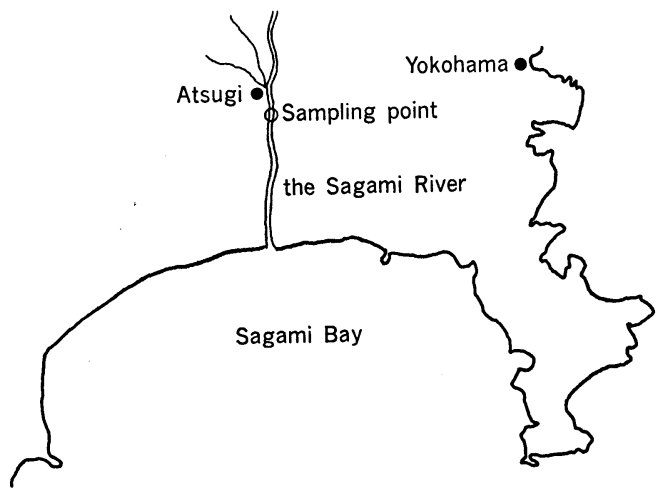

Fig. 1 Securing point of freshwater fish.

except only a few ayu and large mouth bass were caught. The edible part of the fish (only the meat) was used for analysis. Twenty grams of the meat was homogenized with a homogenizer (Biotrone), then cleaned up by following Scheme 1, and F1 was used as a test solution. CNP and chlomethoxynil were measured with N-P FID GC and ECD-GC; benthiocarb and molinate were measured with N-P FID GC and FPD-GC.

\section{Analytical Method of Water}

Two liters of water was taken as a sample from the Sagami River near the point the fish were taken from late May to August and the herbicidal content was analyzed. Five grams of sodium chloride was added to $500 \mathrm{ml}$ of the sample and the sample was extracted successively with $100 \mathrm{ml}$ and $50 \mathrm{ml}$ of $n$ hexane. Then, the $n$-hexane layer was dried with anhydrous sodium sulfate, concentrated to $5 \mathrm{ml}$, and herbicides were measured with a gas chromatograph.

\section{RESULTS}

\section{Recovery Tests}

Twenty grams of homogenized fish meat (crucian carp) or $500 \mathrm{ml}$ of water were fortified with herbicides dissolved in acetone at levels shown in Table 1, and recovery tests were carried out by the described method. Good results were obtained as shown in Table 1 . 


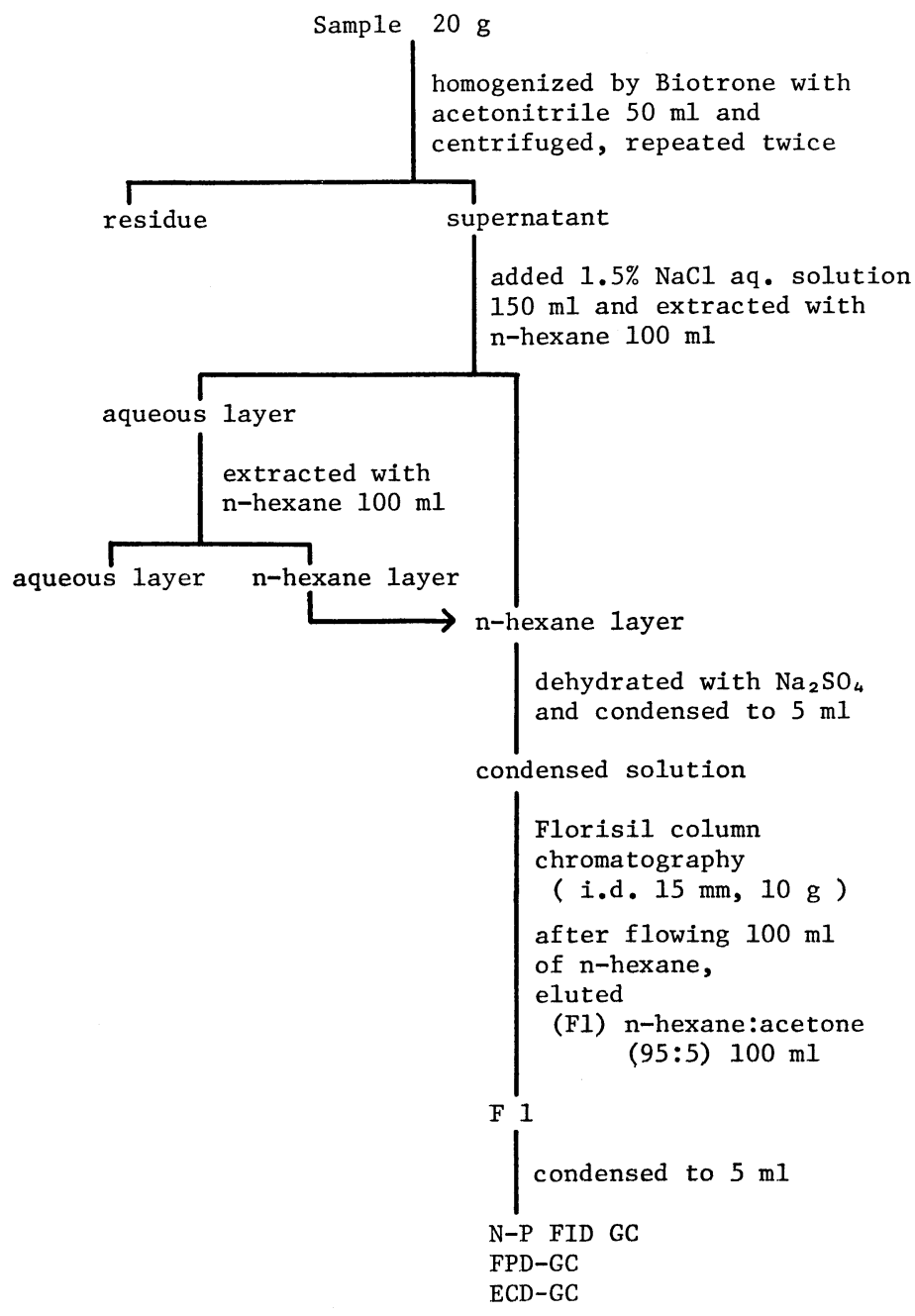

Scheme 1 Method of analyzing herbicides in fish.

2. Residual Levels of Herbicides in Freshwater Fish

Figure 2 shows the gas chromatograms of herbicide standards and Fig. 3 shows the typical gas chromatograms of refined test solution (F1) obtained with N-P FID GC, FPD-GC and ECD-GC.

N-P FID GC has a specific selectivity for nitrogenous and phosphorus compound, and FPD-GC (equipped with $\mathrm{S}$ filter) has a similar specific selectivity for sulfur compound; clear chromatograms could thus be obtained because they accepted little interference by other organic substances. ECD-GC has a higher sensitivity for the measurement of CNP and chlomethoxynil compared to N-P FID GC, but its selectivity is not as good as N-P FID GC.

Table 2 shows typical sizes of samples used and residual levels of herbicides in fish. CNP was detected in all four species, carp (Cyprimus carpio), crucian carp (Carassius gibelio), pale chub (Zacco platypus) and pike gudgeon (Psendogobio esocinus), secured on July 9, 1980 and their residual levels were from $0.055 \mathrm{ppm}$ to $0.61 \mathrm{ppm}$. But CNP was not detected in crucian carp or pale chub which were caught on December 9, 1980. On the other hand, benthiocarb was only detected in two kinds of fishes, crucian carp and pale chub, secured in 

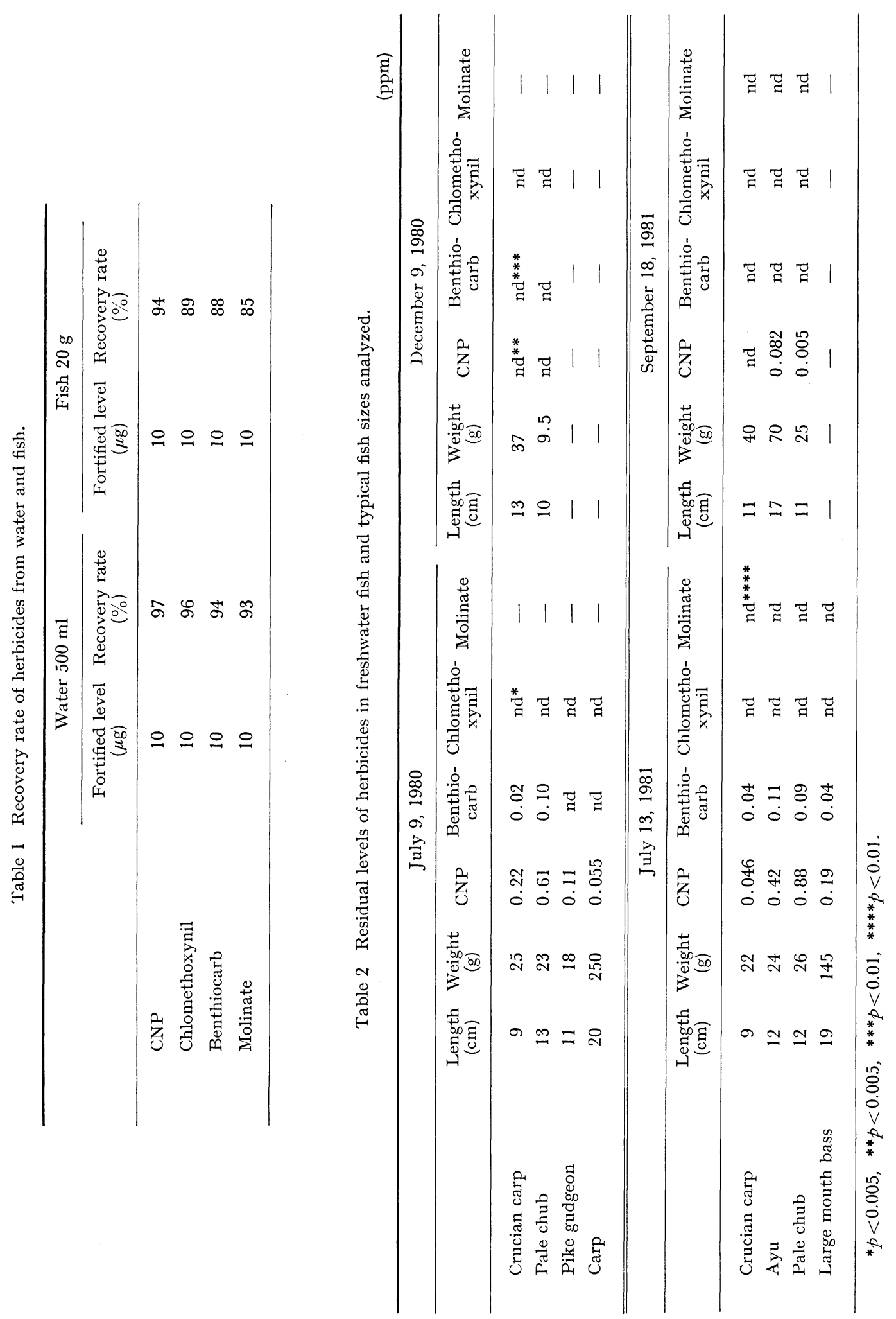

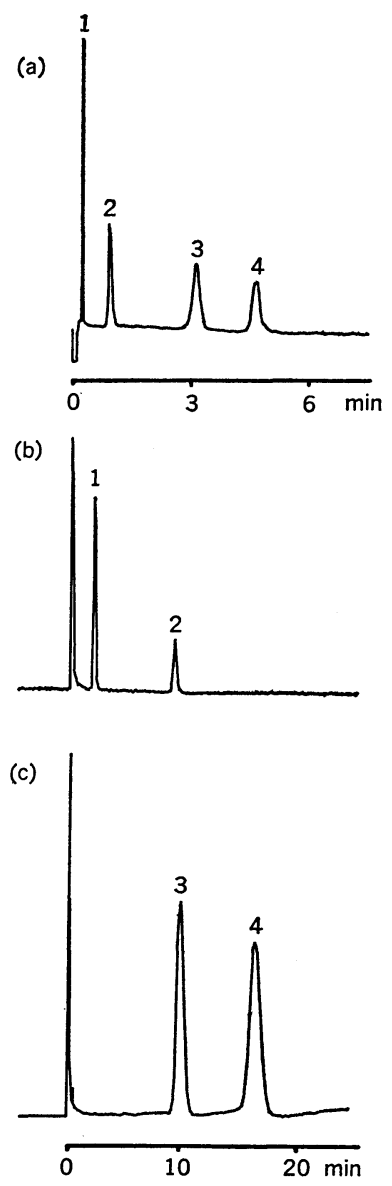

Fig. 2 Gas chromatograms of herbicide standards obtained with (a) N-P FID GC, (b) FPD-GC and (c) ECD-GC.

Peak 1: molinate, 2: benthiocarb, 3: CNP, 4: chlomethoxynil.

July, 1980 and their levels were $0.02 \mathrm{ppm}$ and $0.10 \mathrm{ppm}$. As in 1980, CNP and benthiocarb were detected in all four species, carp, pale chub, large mouth bass (Micropterus salmoides) and ayu (Plecoglossus altivelis), secured on July 13, 1981. Their residual levels of CNP were from $0.046 \mathrm{ppm}$ to $0.88 \mathrm{ppm}$ and those of benthiocarb from $0.04 \mathrm{ppm}$ to $0.11 \mathrm{ppm}$. In September, 1981, however, their residual levels were below a detectable level or detected only at very low concentration. Chlomethoxynil and molinate were not detected in any samples examined. Accurate determination was carried out as follows. After measuring the GC-MS
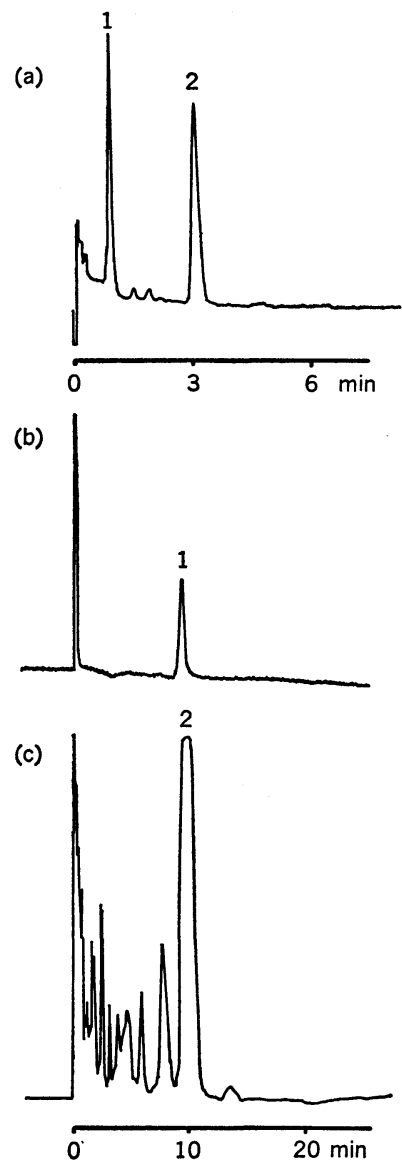

Fig. 3 Typical gas chromatograms of test solution (F1) obtained with (a) N-P FID GC, (b) FPD-GC and (c) ECD-GC.

Peak 1: benthiocarb, 2: CNP.

spectra of CNP and benthiocarb standards (Fig. 4), CNP in the extracted test solution from fish was determined by mass fragmentography of $m / z 319,238$ and benthiocarb by $m / z$ 257.

\section{Contamination Levels of Herbicides in Water}

The herbicidal contamination levels in water of the Sagami River near the point where the fish were taken were investigated from late May to August, and Fig. 5 shows the results. CNP and benthiocarb were detected in water and their detected levels from late June to early July were about $0.1 \mathrm{ppb}$ and $1.4-2.3 \mathrm{ppb}$, 


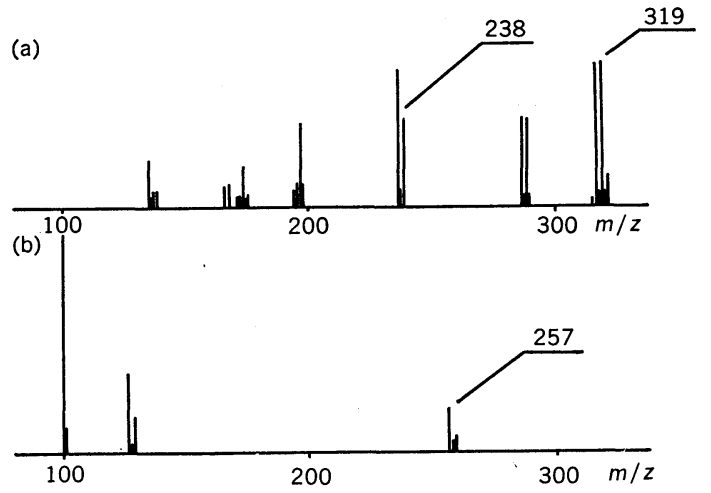

Fig. 4 GC-MS spectra of (a) CNP and (b) benthiocarb standards and indication of mass number for measurement of mass fragmentography.

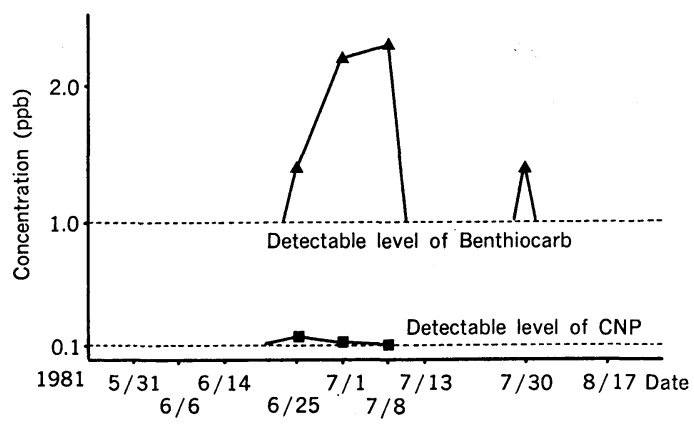

Fig. 5 Contamination levels of $\mathrm{CNP}$ and benthiocarb in water of the Sagami River.

घ: CNP, $\Delta$ : benthiocarb.

respectively. Chlomethoxynil and molinate were not detected throughout the examining period.

\section{DISCUSSION}

CNP and benthiocarb were detected in freshwater fish but it was thought that their residual period did not continue too long. It especially became clear that even if CNP or benthiocarb existed at an extremely low concentration level in water, fishes were contaminated at a high concentration level. Generally, fish take in contamination substances dissolved in water not only directly by gill breathing, but also indirectly through contaminated feed.

It was reported that each bioconcentration ratio (concentration level in fish/concentration level in water) of CNP and benthiocarb was examined in the freshwater fish, topmouth gudgeon, in a breeding tank, and the ratio of CNP was 1,160 while that of benthiocarb $170 .^{9)}$ The bioconcentration ratio of CNP was supposed to be $420-8,000$ and that of benthiocarb to be $20-100$ when estimated from the results of this investigation, simply by comparing residual levels in fish with those in water. The range of residual levels of $\mathrm{CNP}$ and benthiocarb in fish was roughly the same during the two years of investigations. The contamination level differed in the species of fish and pale chub was contaminated with $\mathrm{CNP}$ at the highest concentration both years. Chlomethoxynil and molinate were not detected in water nor in fish. It was confirmed that both molinate and chlomethoxynil flow out with the effluent water when used on paddy fields. ${ }^{10,11)}$ Therefore it was assumed that the contamination of these substances did not come up to a detectable level because the amount of their application is small in Kanagawa Prefecture. ${ }^{2}{ }^{2}$ Degradation of $\mathrm{CNP}$ in soil is rapid ${ }^{12)}$ and it has a very low solubility in water, so it has been thought that the possibility of environmental contamination with this subtance is very low. But judging from this investigation, the bioconcentration ratio of CNP in fish is extremely high in field samples as well as in the results of the breeding tank, so the contamination of CNP to fish and shellfish needs to be carefully surveyed. CNP has low toxicity, ${ }^{13)}$ but Miyauchi et al. ${ }^{14)}$ reported that it was reduced to the amine derivative by carp and rat intestinal microorganisms, and its derivative causes mutagenesis when treated with S-9. ${ }^{15)}$ It is thus necessary to investigate the contamination of fish and shellfish not only with CNP, but also with its metabolites.

\section{ACKNOWLEDGMENT}

The authors wish to thank to Mr. Hidetoshi Sugiyama of Kanagawa Environmental Center for measurement of GC-MS spectra.

\section{REFERENCES}

1) K. Ishizuka \& H. Hyakutake: J. Pesticide Sci. 2, 568 (1977)

2) Japan Plant Protection Association: "Nōyakuyōran," 1980 
3) M. Suzuki, Y. Yamato \& T. Akiyama: Water Res. 11, 275 (1977)

4) M. Suzuki, Y. Yamato \& T. Akjyama: ibid. 12, 777 (1978)

5) M. Kato \& S. Maru: Abstr. Annu. 4th Meet., Pesticide Society of Japan, p. 339, 1979

6) T. Yamagishi, K. Akiyama, S. Kaneko, S. Horii, T. Miyazaki \& M. Morita: Ann. Rep. Tokyo Metrop. Res. Lab. P.H. 30(1), 127 (1979)

7) K. Ishikawa, S. Suzuki, N. Sato, K. Takatsuki \& K. Sakai: J. Food Hyg. Soc. 22, 56 (1981)

8) N. Watanabe, N. Ishida, Y. Ishimaru, Y. Katayama \& S. Kitayama: J. Pesticide Sci. 6, 31 (1981)

9) J. Kanazawa \& J. Tanaka: "Aquatic Organisms and Pesticides, Volume of Theoretical Application," Scientist Inc., Tokyo, p. 25, 1979

10) S. Watanabe, S. Watanabe \& K. Ito: Bull. Kanagawa P. H. Lab. 10, 53 (1980)

11) S. Watanabe, S. Watanabe \& K. Ito: Abstr. Annu. the 7th Meet., Pesticide Society of Japan, p. 319,1982

12) S. Kuwatsuka: J. Pesticide Sci. 2, 201 (1977)

13) Y. Takazawa: Weed Res. (Japan) 25, 60 (1980)

14) M. Miyauchi, M. Takagi \& T. Uematsu: Bull. Jpn. Soc. Sci. Fish. 46, 837 (1980)

15) M. Miyauchi, M. Takagi, M. Haga, Y. Takeo \& T. Sasaki: Abstr. Annu. the 100th Meet., Pharmaceutical Society of Japan, p. 443, 1980
要 約

除草浻（CNP，クロメトキシニル,ベンチオカー ブおよびモリネート) の淡水魚污染調査

渡辺貞夫, 渡辺重信, 伊藤和敏 国内で公範囲に多用されている水田除草郕 (CNP, ク ロメトキシニル, ベンチオカーブ, モリネート）の污染 実態調查を，相模川 (神奈川県) で採取した淡水魚につ いて実施した。これら除草剂の水田への使用は, 田植時 期に限定されるため, 調査を 7 月に行ない, 他の時期の 污染レベルと比較した. 昭和55年 7 月に採取した 4 魚種 (オイカワ, カマツカ, コイ,フナ)すべてから CNP が, また 2 魚種からベンチオカープが検出された. CNP の 残留レベルは $0.055 \mathrm{ppm}$ から $0.61 \mathrm{ppm}$ の範囲で, ベン チオカーブは $0.02 \mathrm{ppm}$ および $0.10 \mathrm{ppm}$ であった. 昭 和 56 年 7 月採取した 4 魚㮔（オイカワ, アニ, フナ, ブ ラックバス) に, CNP が $0.046 \mathrm{ppm}$ から $0.88 \mathrm{ppm}$, ベ ンチオカーブは $0.04 \mathrm{ppm}$ から $0.11 \mathrm{ppm}$ の範囲で検出 され，昭和 56 年の調査結果とほぼ同程度であった。し かし，昭和 56 年 9 月採取した魚には，これら除草剤は いずれも不検出あるいは微量しか検出されなかった. 今 回の調査結果から, CNP の生物濃縮係数は 420 8,000, ベンチオカーブは 20〜100 と想定された. しかし，これ ら除草剤の淡水魚への蓄積残留は比較的短期間であると 考えられた.クロメトキシニル执よびモリネートは，い ずれの検体からも検出されなかった。 